\title{
Certification in Honduras: Perspectives of wood product manufacturers, consumers, NGOs and government forest policymakers
}

\author{
by Richard P. Vlosky ${ }^{1}$, Juan Antonio Aguirre ${ }^{2}$, Edna Carolina Soihet Montes ${ }^{3}$, \\ Lucie K. Ozanne ${ }^{4}$ and Gabriela Silva ${ }^{5}$
}

\begin{abstract}
Although research has been conducted that examines certification issues from stakeholder perspectives in temperate forest regions, very little has been done in tropical supplier countries. This study identifies key certification issues in Honduras, a Central American producer and exporter of forest products. Five stakeholder groups were studied: primary wood products manufacturers, secondary manufacturers, government forestry policymakers, non-governmental organizations and consumers. Results indicate that there a general lack of awareness about certification, an increasing willingness-to-pay for certification as one moves from the forest to the consumer, the need for transparency in the process, and the belief that certification should be conducted by the government at a national level.
\end{abstract}

Key words: certification, wood products, Honduras
Même si des recherches ont été entreprises pour examiner les questions de certification des régions forestières tempérées selon le point de vue des intervenants, très peu de choses ont été faites pour les pays tropicaux fournisseurs de bois. Cette étude identifie les enjeux-clés de la certification au Honduras, un producteur et exportateur de produits forestiers de l'Amérique centrale. Cinq groupes d'intervenants ont été étudiés : les manufacturiers de produits ligneux primaires, les manufacturiers de produits secondaires, les fonctionnaires qui élaborent les lois en matière de foresterie, les organisations non-gouvernementales et les consommateurs. Les résultats démontrent qu'il existe un manque de sensibilisation en général au sujet de la certification, une volonté croissante de payer pour une certification à mesure qu'on se déplace de la forêt vers le consommateur, la nécessité d'obtenir la transparence dans le processus, et la croyance que la certification devrait être entreprise par le gouvernement à l'échelle nationale.

Mots-clés : certification, produits ligneux, Honduras

\section{Overview}

Global interest in forest certification is increasing at both national and international levels. Stakeholder groups, including timberland owners, forest products companies, public forest land managers, non-government organizations (NGOs), environmental associations, industry associations and consumers, are involved in the certification debate. Pressure for sustainable tropical ecosystem management and biodiversity preservation is fostering interest for environmental labels that result from some form of certification. In addition to environmental concerns, there is interest in the promotion of certification from a marketing perspective, with possibilities of increased competitive advantage and access to new markets. Certification has been met with mixed reactions by local authorities, consumers, timber producers and environmentalists in tropical resource-producing regions.

This research is based on the premise that, if instituted, thirdparty certification may affect commercialization of timber and

\footnotetext{
${ }^{1}$ Associate Professor, Forest Products Marketing, Louisiana Forest Products Laboratory, Louisiana State University Agricultural Center, School of Forestry, Wildlife and Fisheries, Baton Rouge, Louisiana, United States.

${ }^{2}$ Senior Research Scientist, Natural Resources Economics and Dean of the Graduate School, Tropical Agricultural Research and Higher Education Center (CATIE), Turrialba, Costa Rica.

${ }^{3}$ Research Associate, Tropical Agricultural Research and Higher Education Center (CATIE), Turrialba, Costa Rica.

${ }^{4}$ Lecturer in Marketing, Department of Economics and Marketing, Lincoln University, Canterbury, New Zealand.

${ }^{5} \mathrm{Ph} . \mathrm{D}$. Candidate in Forest Resources, College of Agricultural Sciences, The Pennsylvania State University University Park, Pennsylvania.
}

timber products in tropical resource regions of the world. While many studies have been conducted that identify certification issues from consumer, wood products manufacturer and other stakeholder perspectives in temperate forest regions, very little is known about these issues from the perspective of a tropical forest-producing nation. Specifically, the purpose of this study is to better understand how forest-related stakeholders in Honduras feel about third-party certification. It needs to be made clear that there are other standards and forest management verification schemes that currently exist. For example, the International Organization for Standardization (ISO), Environmental Management System ISO 14001, is global and can be applied to forest management although it does not result in a product label. Therefore, the distinction between concern for "sustainable ecosystem management" and expression of certification in a product-labelling exercise is a key and often misunderstood one. In addition, in the United States, the American Forest and Paper Association has developed a set of verification second-party standards called the Sustainable Forestry Initiative (SFI) which all members must follow.

Honduras is a Central American producer and exporter of forest products, which has, until very recently, experienced rapid deforestation and lack of comprehensive forest management controls at the national level. Because of its economic and forest structures, Honduras offers a contrast to studies conducted by the authors in Costa Rica, a more developed tropical forest products producer (Soihet 1994), and the United States, the largest global consumer and producer of forest products (Ozanne and Vlosky 1997, Vlosky and Ozanne 1997). 


\section{Forest Products Certification}

Reduction of the world's rain forest and accompanying environmental degradation has been a global issue since the middle of the 20th century. Saving the remaining forests in both tropical and temperate areas has become an important priority of the world community (Rajagopalan 1992). Lead agencies in research and development in this area include the Food and Agriculture Organization (FAO) of the United Nations, the World Bank and the International Tropical Timber Organization (ITTO).

Primary causes of deforestation in developing countries are the transformation of forest lands into agricultural lands and firewood consumption. Certification is suggested by many to be one possible solution by encouraging private and public land managers to manage forest resources in a sustainable manner. It is also suggested as a means to assuage common perceptions that most forest practices involving the harvesting of wood do irreversible damage to the environment (Peterson 1994). One goal of certification, therefore, is to meet the need for consumers to be assured by neutral third-party organizations that forest products companies employ practices that ensure sustainability of the forest. In addition to countering negative perceptions by consumers and the general public, companies that prove themselves to be environmentally responsible may benefit from certification by differentiating their products in the marketplace and thus acquiring a larger share of the market.

The driving force in the certification arena is the Forest Stewardship Council (FSC), created in 1993 in Toronto, Canada and now headquartered in Oaxaca, Mexico. The FSC is a diverse coalition from three distinct interest areas (economic, social, and ecological) that sets international standards for forest management and accredits certifiers. Each area is equally represented and there are rules to assure representation from the northern and southern hemispheres (Hansen 1998). The process of timber certification, as outlined by the FSC, is composed of two phases: certification of sustainable forest management and product certification (Baharuddin 1995). Certification of sustainable forest management occurs at the forest site, either for natural forests or plantations. This process includes all activities from the management of the forest resource to the environmental, economic and social impacts of forest activities. Product certification entails a "chain-ofcustody" audit from the stump, through the manufacturing process, to the ultimate consumer. A key element of the FSC scheme is the incorporation of a logo or eco-label. The label is designed to communicate to consumers that the product comes from a well-managed forest. If eco-labelled products become common in the marketplace, consumers may develop a preference for them (Hansen 1998).

FSC accredits or approves organizations (certifiers) that wish to perform forest certifications according to its ten principles and criteria. Essentially, this means that FSC is the certifier of the certifiers. To date, FSC has accredited a total of five certifiers: Scientific Certification Systems and SmartWood from the United States, SGS Qualifor and The Soil Association from the United Kingdom and SKAL from the Netherlands (Hansen 1998).

FSC has developed ten principles and criteria for forest management designed to assure that consistent performancebased standards are used in evaluating forest management practices. Because the principles and criteria are broad and generic,
FSC facilitates standards development processes in countries or regions around the world. Currently, there are officially endorsed groups operating in six countries and another 20 following FSC frameworks without official endorsement. The FSC also has a policy regarding percentage-based claims. A percentage-based claim allows an assembled, fibre- or particlebased product to carry an FSC label even though only part of its wood fibre is from a certified source. The allowable split is at least $70 \%$ certified and no more than $30 \%$ uncertified, based on volume for assembled products and weight for fibre- and particle-based products. The policy also allows up to $75 \%$ recycled or non-wood fibre in combination with $25 \%$ virgin fibre. At least $70 \%$ of the virgin fibre must be certified (Hansen 1998).

\section{Current Status of Certification in Honduras}

Honduras is situated between $13^{\circ}$ and $16^{\circ}$ North Latitude with an area of $112492 \mathrm{~km}^{2}$. It is one of the seven countries that form the Central America Isthmus. The area covered by forest is $59890 \mathrm{~km}^{2}$ ( $53.2 \%$ of the national territory): 29178 $\mathrm{km}^{2}$ is broadleaf forest, $25127 \mathrm{~km}^{2}$ is pine forest and 5591 $\mathrm{km}^{2}$ is mixed forest. Although deforestation has caused a reduction of 1.65 million ha of the forest resource (COHDEFOR 1997), Honduras possesses great potential to become a timber and nontimber product producer in the region (PROFOR/GTZ 1996). There are five principal types of forests in Honduras: conifer forest (pine tree forest), broadleaf forest, cloud forest, dry forest and mangrove forest (COHDEFOR 1996).

In Honduras, forest land is generally publicly (government) owned. Concessions are granted for managing the forest resources, but is overseen by COHDEFOR, the Honduras Forest Development Corporation. COHDEFOR, created in 1974, focuses on the monitoring and control of forest activities in private and public lands and in the administration of the national forest. COHDEFOR's objectives include sustainable management of the country's forest resources, export control over all primary wood products and promotion of participation by local communities in forest management (Aguirre et al. 1998). Essentially, it is responsible for all stages of forest production, from managing the resource base to industrial processing and commerce. The Board of Directors of COHDEFOR is presided over by the President of Honduras, and comprises a General Manager and the cabinet ministers of Treasury, Economics, Defence, Natural Resources and the Planning Secretariat (FAO 1985).

The adoption of forest certification principles in Honduras has been initiated through a project sponsored by SmartWood. In general, the purpose of the SmartWood Certification Program is to recognize good forest managers through credible, independent verification of forestry practices. Program guidelines are intended to provide forest industry, scientists, environmentalists and the general public with information on the aspects of natural forest management operations that SmartWood evaluates before making certification decisions. In the case of Honduras, as is the case in other countries, SmartWood is contributing towards the development of country-specific guidelines for forestry certification.

In Honduras, the SmartWood certification program has been applied with the cooperation of an in-country, non-governmental environmental organization, Honduras Siempre Verde (Kim Batchelder, Forester, SmartWood Program, E-mail interview, August 29, 1997). The certification assessment evalu- 
ated forestry groups working with COATLAHL, a regional cooperative based on the north coast of Honduras. COATLAHL was founded in 1977 and is one of more than a hundred cooperatives created by the "Social Forestry System" of COHDEFOR. Its most important functions include the management of humid tropical forests for the sustainable production of hardwoods and the improvement of economic, social and cultural conditions for coop members and their communities. With headquarters in La Ceiba, COATLAHL has 13 groups of sawyers and more than 400 members in 13 different communities. The organization's involvement in certification is part of the Proyecto de Desarrollo del Bosque Latifoliado or PDBL, a project underwritten by Canada. Fourteen communities completed a full certification assessment for a total of 18700 hectares of forest under a formal approved management plan. Costs to conduct the assessment were borne by PDBL, Smith \& Hawkens (a US furniture retailer), Victoria Reproductions (a manufacturer depending on tropical timbers from Honduras) and EcoTimber (a California-based log broker).

With regard to customers or markets for products coming from COATLAHL- and PDBL-certified lands, currently, the most interested in certified tropical woods are project corporate participants (Smith \& Hawkens, Victoria Reproductions and EcoTimber). In addition, COATLAHL is working with the Good Wood Alliance to produce and market "green" furniture that they hope to sell in certified wood products markets.

\section{The Study \\ Overview}

\section{Secondary Data Collection}

An examination of the secondary literature was conducted to ensure that important research and information was not overlooked. Research areas of interest were general forest legislation, status of certification, harvest practices and sustainability efforts in timber-producing countries. In addition, input for this project was sought from certification entities such as the Forest Stewardship Council and SmartWood, among others.

In order to put certification into a regional and international context, several research institutions in Costa Rica were consulted. These included the Orton Commemorative Library, the technical staff of the Teaching and Research Tropical Agronomic Institute (CATIE) in Turrialba, the Agriculture Science Inter American Institute in San José and the Alajuela Business Administration Central American Institute. Information about Honduran primary and secondary forest industries was received from the Honduras Forest Development Corporation in Tegucigalpa in regional offices of the country. Also, the Honduras Timber Dealers Association (AMADHO) and the Secondary Wood Products Association in Honduras, both in Tegucigalpa, were consulted. Information regarding environmental non-government organizations (NGOs) in Honduras was sought from organizations in Tegucigalpa as well as the Honduras Development Private Organizations (FOPRIDEH) and VIDA Foundation. Forest sector government officials from COHDEFOR and the Natural Resource Ministry in Tegucigalpa were also consulted. To gather information about the populations of San Pedro Sula and Ceiba, the Census and Statistics and city officials were consulted. Fig. 1 indicates the location of major cities referenced in this article.

\section{Primary Data Collection}

Five stakeholder groups were identified that would be impacted by certification in Honduras. These groups were:

a) Primary Wood Products Manufacturers: the interviews were conducted in Yoro, Olancho, Francisco Morazan, Comayagua and Atlántida. These regions represent 90.3\% of the rough timber consumption in the country. Primary producers in this study were primary producers (sawmills and a plywood mill) that represent the linkage between the forest and the secondary industry in the commercialization chain from the forest resource to the final consumer.

b) Secondary Wood Products Manufacturers: the interviews were carried out in the cities of San Pedro Sula, $\mathrm{La}$ Ceiba and Tegucigalpa where the majority of secondary companies are located. This group represents the valueadding sector for wood with raw materials that come from primary producers. Secondary producers have direct contact with the final consumer and will decide on the purchase of certified sawnwood. They would make the ultimate sale of environmentally certified products to consumers in national and international markets.

c) Consumers: the interviews were conducted in the cities of San Pedro Sula and La Ceiba. Consumers represent the component of Honduran society that will decide on the purchase of environmentally certified wood products.

d) Environmentalist Non-Governmental Organizations (NGOs): the interviews were carried out in the cities of Tegucigalpa, San Pedro Sula and La Ceiba. NGOs represent the organizations associated with the conservation and protection of the country's natural resources. NGOs may possibly become involved in the certification process if it is applied in Honduras.

e) Government Forest Sector Policymakers: the interviews were conducted in the cities of Yoro, La Ceiba, Tegucigalpa and San Pedro Sula. Government officials legislate and enforce forest resources management practices. The government is also the owner of a great part of the country's forests and may potentially be called upon to supervise the certification process at a national level.

The study was conducted through the use of direct interview and personal survey administration: consumers $(n=400)$, primary wood product manufacturers (lumber, plywood, etc.) (n $=47$ ), value-added wood products manufacturers (furniture, cabinets, etc. $(n=40)$, government forest sector policymakers $(n=12)$ and national and international environmental nongovernmental organizations (NGOs) $(n=26)$. One significant challenge in conducting this study was the lack of comprehensive lists for the respondent groups. Since final lists generated by the authors were not exhaustive, convenience samples, not random samples, were used.

\section{Questionnaire Development}

The method used in the collection of the information was the personal interview. This procedure usually requires that the researcher uses prepared questions and records the inter- 


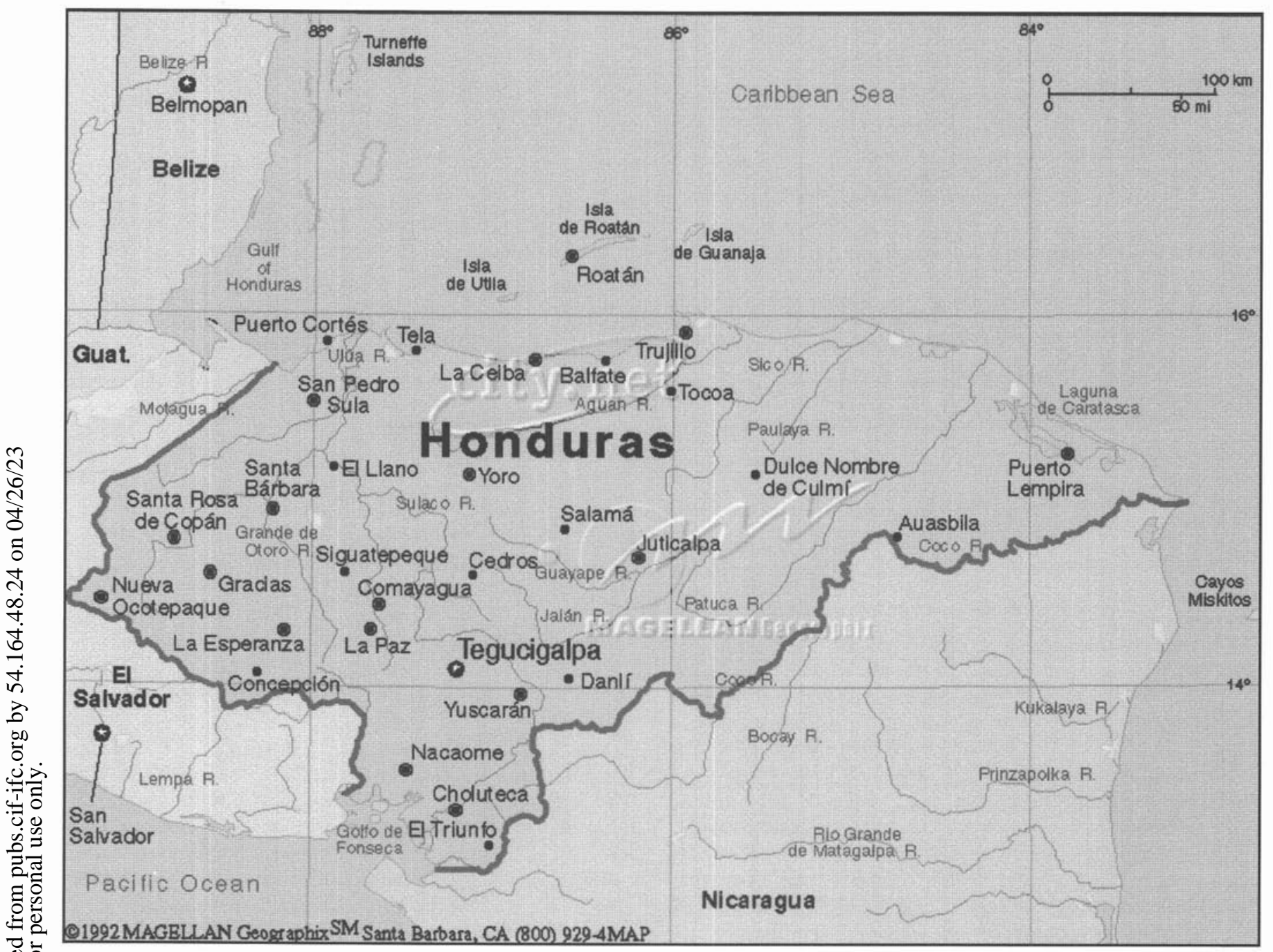

Fig. 1. Map of Honduras

view session. The advantage of using this method is that the people usually answer all the questions when they are face-toface with the interviewer (Mendenhall et al. 1986, Namakforoosh 1987). In the particular case of Honduras, it was decided to use interviews because they adaptable to the environmental, social and economic conditions where people are not accustomed to answering questionnaires by mail or telephone.

The interviewer memorized questions and performed interviews as if they were conversations in order to achieve the confidence of the interviewee and to obtain complete and honest answers. Subsequent to the interview, the answers were entered into a form designed for the project.

\section{Results \\ Respondent Profiles \\ Primary manufacturers}

Primary manufacturers included 46 sawmills and the one plywood manufacturer in the country. All respondents were principals in the company (president or owner). In Honduras, an oligopoly of six large lumber manufacturers constitutes a large proportion of the industry and wields significant leverage in the market place. These six companies control about $20 \%$ of the forest concessions by land area in the country or approximately 500000 hectares and have considerable influence in the determination of prices, demand and supply of forest products in the national market. The balance of the lumber producers was small to mid-size operations, many of which sell their production to the six large operators. Sixtyfive percent of the companies produce less than 1.9 million board feet (MMBF)/year, 29\% produce from 2.0 to 5.9 (MMBF/yr.) and $6 \%$ produce from 6.0 to 9.9 (MMBF/yr.). The majority of the companies are small and use low technology (circular saw) while the few large companies use more advanced sawing technology (band saw). The central region contains more large companies than the eastern and northern zones. The regions of major forest industry development (central and east) contain coniferous forests while the region of lesser development (north) is located in broadleaf forests.

The majority of production (82\%) is sold in domestic markets in Honduras, primarily in metropolitan areas. The balance is sold in export markets in the United States, Europe, Central America and the Caribbean. Both softwood and hardwood lumber is sold rough green. Lumber in this form is often finished and remanufactured in the Caribbean for re-export to markets in the United States and Europe. The fact that so much production is sold domestically has implications for com- 


\begin{tabular}{|c|c|c|c|}
\hline $\begin{array}{r}100 \% \\
90 \%= \\
80 \%= \\
70 \%= \\
60 \%= \\
50 \% \\
40 \%= \\
30 \%= \\
20 \%= \\
10 \%=\end{array}$ & & & \\
\hline & Not Aware & Somewhat Aware & Aware \\
\hline$\square$ Primary Mfgs. $(n=46)$ & $67.4 \%$ & $19.6 \%$ & $13.0 \%$ \\
\hline Secondary Mfgs. $(n=40)$ & $67.5 \%$ & $12.5 \%$ & $20.0 \%$ \\
\hline Consumers $(n=400)$ & $90.5 \%$ & $6.0 \%$ & $3.5 \%$ \\
\hline$\square$ NGOs $(n=26)$ & $46.2 \%$ & $26.9 \%$ & $26.9 \%$ \\
\hline Q Government Officials ( $n=12$ ) & $25.0 \%$ & $50.0 \%$ & $25.0 \%$ \\
\hline
\end{tabular}

Fig. 2. All groups awareness about certification (percent of respondents). municating the certification concept to consumers as domestic acceptance will be a prerequisite for a national certification effort to succeed.

\section{Secondary manufacturers}

Secondary, or value-added, manufacturers are those firms that take primary products such as lumber, plywood and particleboard, and further process them into finished or semi-finished products. All secondary producers in this study were furniture manufacturers. Respondents were principals in the company (president or owner). Nearly $60 \%$ of the firms surveyed had less than 40 employees and just over $20 \%$ have over 120 employees. San Pedro Sula is the centre of industrial development where the largest secondary companies are located. Raw materials in this region are from both coniferous and broadleaf forests. Tegucigalpa, with a lower level of industrial development, was characterized by medium size companies that use conifer raw materials. La Ceiba, with the least developed secondary industry, primarily uses raw materials from broadleaf forests.

Given that many such producers in Honduras are small "mom and pop" operations, this sample frame is biased toward larger and more influential producers. Paralleling firm size is the percent of production that is exported. Respondents export almost $70 \%$ of production with major markets being the United States, Europe, Central America and the Caribbean. Given that certification is being driven by forces in the U.S. and Europe, many Honduran secondary manufacturers are susceptible to export market-driven influences.

\section{Consumers}

Four hundred Honduran consumers from the three metropolitan areas in the country (La Ceiba, San Pedro Sula and Tegucigalpa) were interviewed. The majority of the consumer respondents are relatively young people with a mean age of 36 years. Average monthly income is 5860 lempiras (US $\$ 451)$. This age group typically purchases the largest quantity of wood products and, thus, they will have a major influence in the purchase of certified products. Presumed consumer demand for certified wood products is one of the primary drivers for certification.

The secondary wood products most preferred by respondent consumers across the three income classes are furniture, doors and windows. Study results indicate that furniture is the most purchased product across all income classes. As income increases, the consumption of crafts increase and timber purchases decrease. Timbers are typically purchased by lower economic classes in the construction of houses. In the middle and high economic classes, timber is further processed and used for interior decoration. The majority of respondents prefer dimension or pre-cut wood in these applications.

\section{Non-governmental organizations (NGOs)}

Because non-governmental organizations (NGOs) are often involved in environmental activities, 26 such entities were interviewed. The primary missions of the NGOs interviewed vary and are not strictly limited to environmental or natural resources-based organizations. Three-fourths of the funding for NGO respondents comes from international sources, primarily the World Bank, the World Wide Fund for Nature and the Central America Institute for Development. Of the remaining funding from national sources, $70 \%$ comes from private sources and the balance coming from the government.

There is not a standardized concept about sustainability in the non-government institutions. Some organizations handle certain elements of forest-related issues but exclude others because they do not fit the organizational mission. In general, the interviewed NGOs are aware of some elements of sustainability and sustainable development, but definitions are not uniform. Since many of these institutions promote the sustainable management of resources, this lack of a common direction in forest management will impact participation in future programs of certification.

\section{Government officials}

Twelve officials from the (COHDEFOR) were interviewed at their central headquarters in Tegucigalpa and in regional offices located in San Pedro Sula, La Ceiba, Catacamas, Juticalpa, Yoro and Atlántida. We did not interview government officials outside of COHDEFOR as this is the only agency involved in forestry issues in Honduras.

\section{Combined Results for All Groups Awareness about Certification}

Fig. 2 summarizes general awareness of the notion of certification across the five groups studied. Overall, consumers 


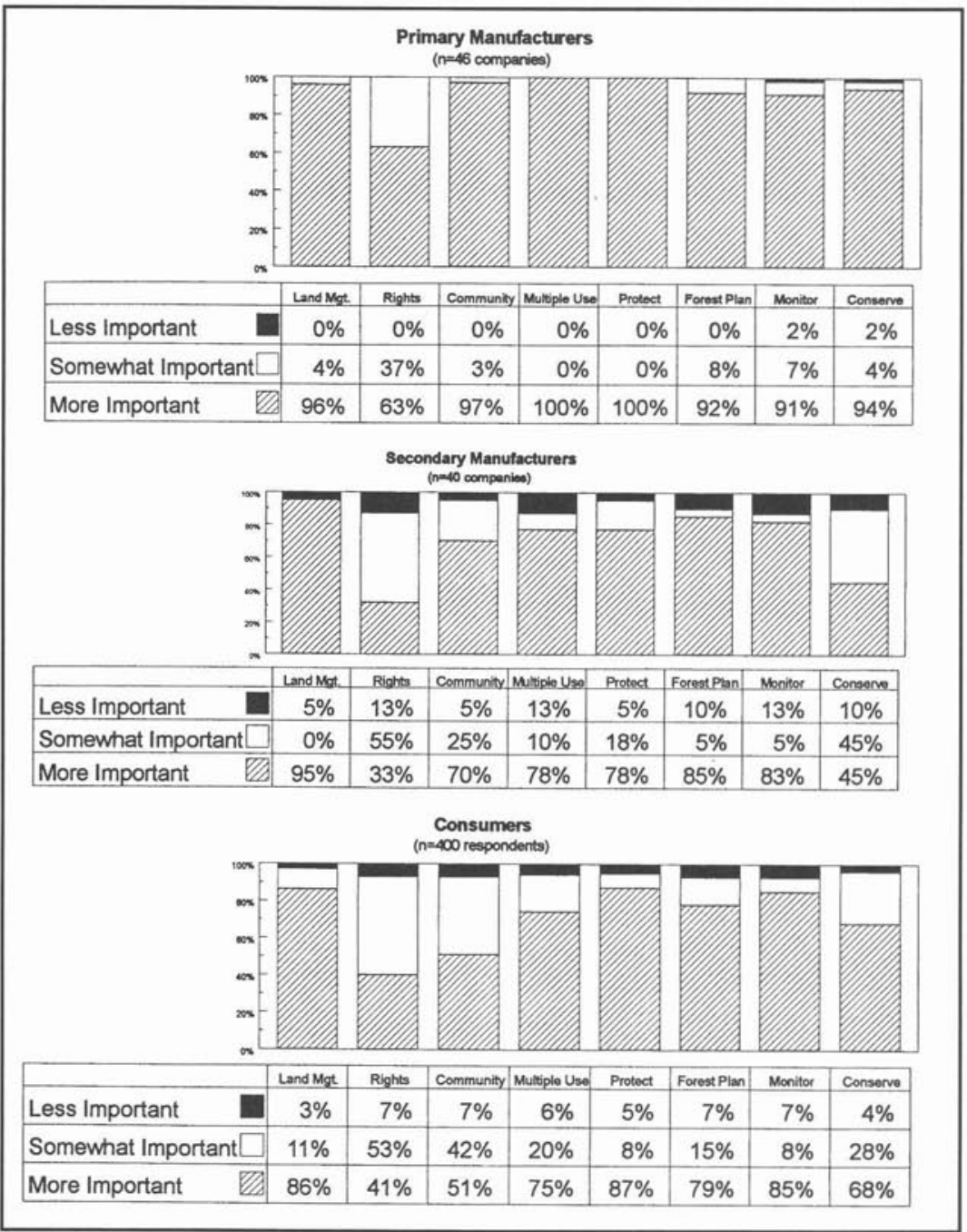

Fig. 3. Importance of criteria for certification to occur. had the lowest level of awareness ( $90.5 \%$ of respondents) while only $25 \%$ of government officials were unaware. Slightly more than two-thirds of primary manufacturer respondents were not aware of certification. The $13 \%$ that fully understood were the larger companies that are more involved in export markets. For many manufacturer respondents, certification was confused with phytosanitary certification required by many importing countries. One respondent showed us his phytosanitary certificate to prove that he was already certified.

Similar to primary producers, only $20 \%$ of secondary manufacturers were aware of certification efforts while $68 \%$ were unaware and the balance had heard something about the concept but were unsure. Nearly half of NGO respondents $(46.2 \%)$ were not aware of forest certification with the balance evenly split between being somewhat aware and definitely aware.

Clearly, the level of awareness about certification at the outset of the interviews was very low. However, the concept was subsequently explained to each interviewee before additional questions were asked. The interview process allowed for probing and interventions that helped to clarify points and definitions.

\section{Criteria for Certification to Occur}

Consumers and manufacturer respondents were asked to evaluate the importance of criteria necessary for certification to occur. Fig. 3 indicates the percentages of respondents by group across three levels of importance. The key for the criteria is as follows:

- Land Mgt. - Land management objectives should be well defined.

- Rights - Legal and property rights of local and indigenous people should be respected.

- Community - Communities should be involved in the certification process. Certification should benefit these communities.

- Multiple Use-Multiple use forest objectives should be taken into account.

- Protect-Certification should serve to promote conservation and forest protection.

- Forest Plan - A forest management plan should exist.

- Monitor - Supervision and monitoring of forest management should take place.

- Conserve - Natural forests should be conserved over time.

Results indicate that manufacturers and consumers deemed most criteria either "somewhat important" or "more important." On average, secondary manufacturers had the highest percentages of "less important" responses followed by consumers. The forest industry in Honduras has historically been one of extrac- 
Primary Manufacturers

( $n=46$ companies)

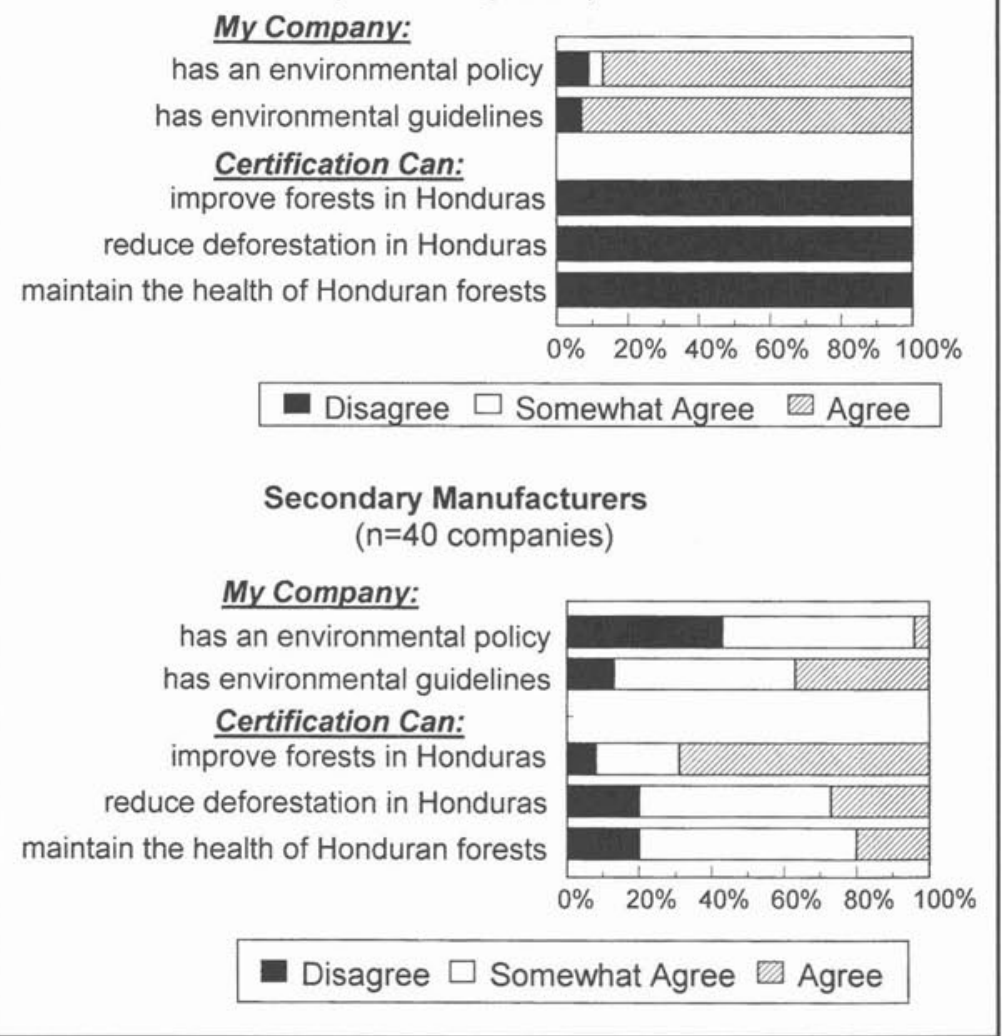

Fig. 4. Company certification perceptions. tion. Although manufacturers are primarily concerned with securing raw material supply for their facilities, management, planning and certification are seen as potentially possible given certain prerequisites. One interesting point is that all three groups deemed accommodating the rights of local and indigenous people in the process of lowest importance.

\section{Manufacturer Certification Perceptions (Primary and Secondary)}

Both primary and secondary manufacturer respondents were asked whether their companies had an environmental policy or guidelines. They were also asked whether certification could improve forest health and reduce deforestation in Honduras (Fig. 4). Primary manufacturer respondents believe that their companies have environmental policies and guidelines. One respondent mentioned that they publish a corporate newsletter that touts the company's environmental activities. All primary manufacturer respondents disagreed that certification could improve forest health or reduce deforestation in Honduras. For the most part, they felt that current management plans administered by COHDEFOR were adequate.

On the other hand, secondary manufacturers were less in agreement that their companies had environmental policies. Contrary to primary manufacturers, they were in general agreement that certification could be beneficial to the health of Honduran forests with only $20 \%$ in disagreement.

\section{Inclination to Pay a Price Premium}

A critical issue associated with certification is the willingness to pay for certified raw materials or final products. The data show that the further one gets from the forest in the market chain, the greater the stated willingness to pay for certification. For example, only $26 \%$ of primary manufacturer respondents said they would pay a certification premium, while $45 \%$ and $79 \%$ of secondary manufacturers and consumers, respectively, would pay such a premium. Coupled with increased overall willingness to pay is the fact that the percentage premium that consumers are willing to pay is considerably higher than those that manufacturers are willing to pay. Ninety-five percent of all manufacturers (primary and secondary) said they would pay only between $1 \%$ and $5 \%$ more for certified raw materials. Consumers, however, on average, said they would pay $12.5 \%$ more depending on the product offered. Of all the groups surveyed, primary manufacturers had the highest percentage of respondents that would not pay a premium for certified raw materials ( $74 \%$ of respondents). Fifty-five percent of secondary respondents would not pay any premium and only $21 \%$ of consumers said that they would not pay any premium. It needs to be made clear that the willingness to pay any premium on the part of manufacturers was tied to the assumption that they, in turn, would receive at least that much from their customers. In addition, although willingness-to-pay research gives researchers and practitioners a great deal of useful information, critics contend that these types of studies do not tell us what consumers in reality will pay (McKillop 1992).

\section{Who Should Certify?}

All respondent groups were asked to indicate who they believed should do the certifying in Honduras if certification was to become a reality. Ninety-one percent of primary manufactures believe 
that a Honduran entity at the national level should be involved. More often than not, the national forestry agency, COHDEFOR, was identified as the preferred agency. This is because COHDEFOR is the best known agency with a presence countrywide. The balance of respondents $(9 \%)$ indicated that associations or non-government organizations should be the certifier.

Similarly, $61.3 \%$ of secondary manufacturers believe that COHDEFOR is the preferred certifier agency. The main reason COHDEFOR was chosen is that it is considered the traditional forest management entity in Honduras. NGOs on the other hand are perceived as having a questionable record of performance. The balance of respondents indicated that the wood industry $(21.3 \%)$, an international certification entity $(12.9 \%)$ or a national non-government organization $(4.5 \%)$ should be the certifier.

For consumers, $49.4 \%$ of respondents believe that COHDEFOR should certify Honduran forests. The balance of respondents indicated that the wood industry $(26.2 \%)$, a national nongovernment organization (15.9\%) or an international certification entity $(8.5 \%)$ should be the certifier. Given that certification efforts are promulgated by international entities, it is important to note that less than $10 \%$ of respondents believe international certifiers should be the certifier in Honduras. The fact that the majority of respondents thought that COHDEFOR, a government entity, should be the certifying agency suggests a lack of understanding of the basic principles of certification, as applied to forestry and forest products on a global level.

\section{Prerequisites for Participating in Certification}

Each stakeholder interviewee was asked to discuss prerequisites that would have to exist before they would consider involvement in certification. Transparency, the sharing of clearly communicated information in an open and easily accessible manner, was important to all groups. Also, the desire for participation by the state as the supervisor of any potential certification process was felt to be essential due to the fact that the government is in charge of management of the forest resources of the country and is the owner of most forest land. In addition, respondents felt that a voluntary system of certification would fail in the objectives of improving forest management and decreasing deforestation since it would create advantages for few people. Finally, the sentiment was strong that certification should be instituted at a national level.

One hundred percent and $70 \%$ of primary and secondary manufacturer respondents, respectively, stated that certification would have to be profitable for them to consider participation. Certification has been found to be a market-driven activity and economic considerations are paramount to participation. The second most selected prerequisite for this group is the need for transparency in the process. Information must be conveyed in an open forum to participants. There was a high degree of suspicion and distrust on the part of primary producers with regard to certification. There was a sense that something was "going on behind their backs." The need for a neutral certifier was also cited as an important criterion, which may be contradictory to the desire that the national government be the certifier. The opportunity to subvert the certification process was felt to be very real and producers said they would not participate if opportunism on the part of the certifier exists. Guaranteed markets for certified products (once again at a profit), the prestige of being perceived as "green" and the need for qualified personnel doing the certifying were also cited as prerequisites although to a lesser degree.

Consumer respondents indicated a willingness to purchase certified wood products but were also concerned about a number of issues. Consumers felt that product quality should not suffer as a consequence of being certified. If a premium is to be paid, they reasoned, then product quality should even be superior relative to the non-certified alternative. Overall, consumers equate certification with quality and feel that if certification occurs, quality will follow. This is an interesting dimension as it focuses on the product and not the process of certification. Also important for over a third of respondents is the need for transparency, or openness in the process and administration of certification. Implementation of necessary regulations was also identified as an important prerequisite to certification.

Forty-two percent of NGO respondents indicated their organization would be interested in becoming a certifier in Honduras. Of the eleven NGOs that would participate, the perceived additional prestige that accompanies being a certifier was the most-indicated prerequisite for participation. Guaranteed funding and financial support was second (73\% of NGOs) and transparency was third (36\% of NGOs). Only 19\% indicated that the need for forest management was a requirement for their participation.

Finally, of the eight government agency respondents that found certification to be an important issue, all agreed that implementation needed to be applied at the national level. Six respondents felt that the need for transparency was a prerequisite while two indicated that there was both a need for more information on the subject and that qualified personnel needed to be involved.

\section{Summary}

This study has identified certification issues from a number of perspectives in a tropical wood product-supplying country. The consistent themes that ran through all groups surveyed were a general lack of awareness about certification, increasing willingness to pay for certification as one moves from the forest to the consumer, the need for transparency in the process, and the belief that certification should be conducted by the government at a national level.

The degree of knowledge about certification is very limited with only government officials and NGOs having adequate information. However, once the concept was explained and understood, there is a willingness to participate in such a process as reflected by willingness to pay additional costs that may be involved in implementing the system of timber certification.

This willingness to pay and participation, in general, in certification were qualified by a set of criteria that each of the groups involved felt should be met before they were willing to give the certification process their full support. The criteria or conditions that a certification system should meet, as reflected by the opinions expressed by the five respondent groups, are potential sources of technical, social, political and economic conflicts that cannot be overlooked if the future success of a potential certification system is to be guaranteed in Honduras. 


\section{Acknowledgements}

This research was made possible by a grant from The John D. and Catherine T. MacArthur Foundation.

\section{References}

Aguirre, J.A., R.P. Vlosky, E.C. Soihet Montes, L.K. Ozanne and G. Silva. 1998. Implications of Environmental Certification on Sustainable Management of Tropical Rain Forests in Central America: A Pilot Study in Honduras. Final Report to sponsor. The John D. and Catherine T. MacArthur Foundation. 131 p.

Baharuddin, H.J. 1995. Timber Certification: An Overview. Unasylva $183(46)$ : $18-24$.

COHDEFOR (Honduras Forestry Development Corporation). 1996. Honduras Forestry Sub Sector Analysis. German Cooperation.Graficentro Editors. Tegucigalpa. Honduras. 496 p.

COHDEFOR (Honduras Forestry Development Corporation) 1997. Statistical Yearbook. Tegucigalpa. Honduras. 94 p.

FAO. 1985. Intensive multiple-use forest management in the tropics: Analysis of case studies from India, Africa, Latin America and the Caribbean. FAO Forestry Paper 55. Rome.

Hansen, E. 1998. Certified Forest Products Marketplace. Chapter 3 in Forest Products Annual Market Review, 1997-1998. Timber Committee. Food and Agriculture Organization of the United Nations. Geneva. Switzerland.

McKillop, W. 1992. Use of contingent valuation in Northern spotted owl studies: A critique. Journal of Forestry. 90(8): 36-37.
Mendenhall, W.L. Ott and R.L. Shaeffer. 1986. Elementary survey sampling. Wadsworth Publishing Co. Inc. Boston, MA.

Namakforoosh, M.N. 1987. Research Methodology. Limusa Editors. Mexico. 531 p.

Ozanne, L.K. and R.P. Vlosky. 1997. Willingness to Pay for Environmentally Certified Wood Products: The Consumer Perspective. Forest Products Journal. 47(6): 1-8.

Peterson, C. 1994. Green certification of wood. Current Issues in Forestry. University of Massachusetts Cooperative Extension System. 6(1).

PROFOR/GTZ. Forestry Project/German Cooperation. 1996. Forestry Action Plan. 1996-2015. Graficentro Editors. Tegucigalpa. Honduras. 316 p.

Rajagopalan. 1992. In the Challenge of Sustainable Forest Management: What future for the world's forest? Food and Agriculture Organization of United Nations (FAO). Rome, Italy.

Soihet, E. 1994. Knowledge, Acceptance, and Implications of the Possible Application of a Wood Certification System in the Sustainable Management of Forests in Costa Rica. Master's Thesis. Turrialba, C.R. CATIE, 120 p.

Vlosky, R.P. and L.K. Ozanne. 1997. Environmental Certification: The Wood Products Business Customer Perspective. Wood and Fiber Science. 29(2): 195-208. 